\title{
Impact of Entrepreneurship Education on the Entrepreneurial Intentions of Students in Technical and Vocational Education and Training Institutions (TVET) In Malaysia
}

\author{
Wan Nur Azlina Ibrahim ${ }^{1}$, Ab. Rahim Bakar ${ }^{1}$, Soaib Asimiran ${ }^{1}$, Shamsiah Mohamed ${ }^{2}$ \& Noor Syamilah Zakaria ${ }^{1}$ \\ ${ }^{1}$ Faculty of Educational Studies, Universiti Putra Malaysia, Malaysia \\ ${ }^{2}$ Faculty of Science, Universiti Putra Malaysia, Malaysia \\ Correspondence: Ab. Rahim Bakar, Faculty of Educational Studies, Universiti Putra Malaysia, Serdang, Selangor, \\ Malaysia. Tel: 60-389-468-210. E-mail: abrahimbakar@yahoo.com
}

Received: June 22, 2015 Accepted: July 25, 2015 Online Published: November 25, 2015

doi:10.5539/ies.v8n12p141 URL: http://dx.doi.org/10.5539/ies.v8n12p141

\begin{abstract}
The purpose of this study was to determine the entrepreneurial intention level of vocational and technical students in Malaysia. A total of 289 final year students who were enrolled at two different TVET institutions (community colleges and National Youth and Skills Institutes) were chosen to participate in the study. The findings indicated that students have a strong interest in entrepreneurship (mean = 4.23, S.D. $=0.73)$ and a high level of entrepreneurial attitudes $($ mean $=4.03$, S.D. $=0.47)$. It was also revealed that their social norms $($ mean $=$ 3.82, S.D. $=0.59)$, entrepreneurial efficacy $($ mean $=3.99$, S.D. $=0.59)$, and efficiency of entrepreneurship knowledge $($ mean $=3.93$, S.D. $=0.55)$ were at moderate levels. There was no significant difference in the entrepreneurship intentions between students from community colleges and students from National Youth and Skill Training Institutes $\left(\mathrm{t}_{260}=.23, \mathrm{p}=.82\right)$.
\end{abstract}

Keywords: entrepreneurial intention, Theory of Planned Behavior, technical and vocational education and training (TVET)

\section{Introduction}

In his research report, Kirchberger (2008) explained that Technical and Vocational Education and Training (TVET) in Asia is undergoing change to provide students with basic skills and specific knowledge in addition to providing them with a "tool" to enhance their knowledge through lifelong learning and to create self-employment. Emphasis is placed on the skills and basic knowledge needed for industry and commerce for the students to be independent, as explained by Kirchberger (2008), who emphasized aspects of the training content that are not only focused on specific jobs but also on career clusters of other related jobs. This action is seen to be essential in training the labor force to be multi-talented as well as to provide the work experience needed to enhance student skills. Kirchberger (2008) also spoke about the changes that have occurred in the TVET systems in Bangladesh, Thailand, Korea, Singapore, Indonesia, China, and Malaysia. Among others, they introduced a dual system through the integration of courses and industrial training together with the operation of a business in related institutions, and they encouraged the private sector to play a major role in providing technical and vocational education that is in line with industry needs.

Kirchberger's (2008) report is consistent with previous research reports by Haftendorn and Salzano (2004). Haftendorn and Salzano's (2004) research reported that in most countries, such as Finland, Germany, Singapore, Chile, and many others. These countries have been and are reforming their Technical and Vocation Education and Training (TVET) systems to adapt them to each country's economic growth. Similarly, research report by Chou, Shen, Hsiao, and Chen (2010) showed that Taiwan has made changes in her education system, especially in Technical and Vocational Education and Training (TVET) in accordance with the labor market's needs.

Reports by Kirchberger (2008), Haftendorn and Salzano (2004) and Chou and colleagues (2010) showed that with the current changes that occur with the increasing population, especially in the younger generation, intense competition in the job search demands earnest attention to creating a skilled workforce in terms of employment and self-reliance. Therefore, the TVET system is expected to provide a career path and personal development among trainees that is comparable to a career path based on academic qualifications through skills training that 
focuses on the acquisition of knowledge, skills and specific abilities. According to the Federal Ministry of Education and Research (BMBF) of Germany (2005) in a report entitled, "Reform of Vocational Education and Training in Germany: The 2005 Vocational Training Act," the reformation (reform) goals for Vocational Skills Training (VET) in Germany are intended to ensure that the younger generation of people that is entering the working environment is able to apply previously learned skills and that they will be self-reliant in their employment.

As an added value to students, entrepreneurship education was first applied to the educational curriculum, including the Technical and Vocational Education and Training (TVET) curriculum. The aim was to develop and enhance the core competencies of students who are starting a business. According to Schoof (2006), entrepreneurship and self-employment can be a source of new jobs and dynamic economics in developed countries, and it can improve the quality of life and the economy of the younger generation in developing countries. Schoof's (2006) opinion was supported by Matlay (2008) through a study entitled "The Impact of Entrepreneurship Education on Entrepreneurial Outcomes." Matlay (2008) reported that entrepreneurship education has a positive impact on the production of entrepreneurs, whereby many graduates began to open their own businesses, which ultimately grew into strong companies. Studies have also shown that individuals with high entrepreneurial qualities will be active, flexible, able to adapt to a learning environment and able to see change as an opportunity (Chou \& friends, 2010; Shartrand, Weilerstein, Besterfield-Sacre, \& Olds, 2008). Entrepreneurship provides space and opportunities for individuals to work on the things they want to explore and creates opportunities that allow lucrative returns. Entrepreneurship also provides an opportunity for all individuals to improve their economic situations and society. Even if these students do not start businesses in the future, they may be able to use the knowledge and entrepreneurial skills they learned to help in their work. As a result, many countries are engaged in reforming their vocational and technical training skills (TVET) systems by inserting entrepreneurship education into their technical education curricula (Haftendorn \& Salzano, 2004).

A study by Shen and Chai (2006) on 760 students in four polytechnics and three universities in Singapore showed that the introduction of entrepreneurship education into the curricula of polytechnics and universities in that country successfully transformed their interests in entrepreneurship and their perceptions about entrepreneurship. Research findings by Shen and Chai (2006) were consistent with a study conducted by Wang and Verzat (2011) that addressed the readiness level of engineering students to venture into the entrepreneurship field by using two different curricula (with a curriculum related to management and entrepreneurship; the traditional curriculum only emphasized the engineering field). Wang and Verzat (2011) found that student exposure to the curriculum related to management and entrepreneurship helped to produce more students with a strong entrepreneurial determination than the students in the traditional curriculum that only emphasizes engineering.

Based on a study by Norfadhilah and Halimah (2010), approximately 420 students from three universities, namely Universiti Teknologi Malaysia (UTM), Universiti Utara Malaysia (UUM) and the International Islamic University Malaysia (IIUM), reported that profit-oriented factors and the desire to achieve excellence in life are the primary concerns that influence students to become entrepreneurs. According to Norfadhilah and Halimah (2010), $80 \%$ of respondents have positive attitudes towards entrepreneurship, even though only $58.8 \%$ of them on the whole are interested in becoming entrepreneurs. Attitude is a key variable that impacts one's determination, and an attitude will drive a person to behave accordingly (Norfadhilah \& Halimah, 2010). The study showed that attitude is an important factor in influencing student entrepreneurial intentions. Most respondents expected that their positive attitudes towards entrepreneurship could be maintained until they started their business in the future.

\subsection{Background of the Problem}

Kourilsky and Walstad (2007) suggested that entrepreneurship education should start in school. Their rationale was because schools are now trying to produce salaried workers rather than job makers. Therefore, schools are not trying very hard to equip students with the knowledge necessary for them to develop the economy (Kourilsky $\&$ Walstad, 2007). The second reason given by Kourilsky and Walstad (2007) is that all upper secondary students in tertiary education who go through the learning process in a school/institution of higher education would go into an economic field that offers fewer opportunities in addition to other factors such as changes in the current economy and globalization and development in R \& D and technology. The opinion of Kourilsky and Walstad (2007) is based on the results of their study of high school students in the United States, the public and small business owners.

Furthermore, a study by Kourilsky and Walstad (2007) showed that $65 \%$ of surveyed U.S. high school students 
prefer to work on their own (start a business). However, because of their lack of entrepreneurial education and the negative impression given by the media about business/entrepreneurial causes their interest in entrepreneurship slightly declined. Moreover, despite their desire to become entrepreneurs, students are still lacking in terms of entrepreneurial skills; they do not understand business management and they do not understand economic knowledge (Kourilsky \& Walstad, 2007). The same survey reported that $20 \%$ of small business owners in the study became interested in becoming an entrepreneur when they were younger than 20 years of age; $20 \%$ were between the ages of 20 and 24 years, $30 \%$ were between 25 to 30 years old, and the remaining $30 \%$ became interested after reaching 30 years of age.

Hisyamuddin (2010) argued that early exposure to entrepreneurship at a young age is one of the important aspects needed to enhance entrepreneurship. Regardless of the course they choose, students still acquire benefits from being nurtured in entrepreneurship education at a young age through innovative problem solving skills, the ability to adapt to changes, and greater creativity. A literature review by Zaidatol and Bagheri (2011) noted that some researchers argued for the importance of nurturing entrepreneurship at a young age because that is an appropriate time to embed a positive attitude in students towards entrepreneurship. In addition, other researchers have also indicated that student levels of entrepreneurial self-efficacy are high. Thus, the tendency to become an entrepreneur is also high. Therefore, early aspirations towards entrepreneurship can be formed at the secondary education level.

Although every country views entrepreneurial activity from different perspectives depending on their cultures, encouragement for entrepreneurs is the policy of most countries today, and the primary objective is to generate employment opportunities through an effort to create self-employment (Haftendorn \& Salzano, 2004). Policy makers believe that an increased level of entrepreneurship can be achieved through education (European Commission, 2006), particularly entrepreneurship education. According to Mohd Khata and Ahmad Firdaus (2012), some researchers found that the most effective way to achieve the government's aim is to provide people with education and knowledge in the field of entrepreneurship. However, a study by Cheng, Chan, and Amir (2009) with 300 respondents from two public universities, two private universities, and a private college in Malaysia showed that the level of understanding about "what is entrepreneurship" is still low among the respondents selected for this study.

Norfadhilah and Halimah (2010) reported that although the results showed that students in the three universities (UUM, IIUM and UTM) have a high level of interest in entrepreneurship. This finding is further supported by (Zaidatol \& Bagheri, 2011). According to Zaidatol and Bagheri (2011), previous studies reported that the primary challenges faced by entrepreneurship educators are the efforts needed to attract and develop natural talents and entrepreneurial ability (Zaidatol \& Bagheri, 2011). According to the authors, these factors have given rise to continuous dispute among scholars/intellectuals about the need for and importance of applying entrepreneurship education to students at the school level.

Although this field of research has become increasingly popular, a review of the literature shows that most studies on entrepreneurship that were conducted inside or outside the country focused on high school students, institutions of higher education (universities), businessmen/entrepreneurs, academics and others. Until the present, few studies have been reported in connection with students in vocational training institutions in Malaysia. This opinion was supported by Mohd and Ahmad (2012), who showed that most studies related to entrepreneurship are more geared to business management students who have been given exposure to basic course in entrepreneurial knowledge. Individuals/engineering students are also given this opportunity because this group has received training in skill training centers such as the National Youth Training Institutes or 'Institut Kemahiran Belia Negara' (IKBN), Institut Latihan Perindustrian (ILP), Pusat Giat Mara and Institut Kemahiran Mara (IKM) (Mohd \& Ahmad, 2012).

\subsection{Problem Statement}

Vocational education programs are able to provide the best environment for entrepreneurship training for students (Bettencourt, 1980). Vocational educators have noted that starting a business is a natural result of vocational skills training, and these educators have continued to foster the entrepreneurial spirit in all types of young people (Ashmore, 1990). In their report to policy makers in Europe and the United States, Oosterbeek, Praag, and IJsselstein (2008) stated that entrepreneurship is important for a higher level of economic growth and innovation. Because entrepreneurship plays a significant role in economic development and innovation, it is now included in the national curriculum for Technical and Vocational Education and Training (TVET) in most European countries (European Commission, 2009). The report also indicated that students in European countries participated in some form of entrepreneurial activities during their study. Steps are taken by the Governemnt o 
Malaysia to encourage TVET graduate to go into entrepreneuship by offering entrepreneurship course in TVET curriculum

According to Hamidi, Wennberg, and Berglund (2008), previous studies indicate that not much is known about the influence of entrepreneurship programs on the entrepreneurial behavior of students, although participation in these programs is meant to enhance entrepreneurial intentions. The latest research by Mohd Khata and Ahmad Firdaus (2012) about entrepreneurial inclinations among technical field students only followed students in IKM Johor Bahru and IKM Jasin, even though there are a few more Public Skills Training Institutes (PSTI) or 'Institusi Latihan Kemahiran Awam (ILKA)' operating in Malaysia. The researchers felt responsible for tracking technical entrepreneurship students from other training institutions. For this study, the researchers chose two (Public) Education and Technical and Vocational Education Training (TVET) institutions in Malaysia, namely community colleges and NYSI. A review by Autio, Keeley, Klofsten, Parker, and Hay (2001) of previous studies related to entrepreneurship choice involved the application of the theory of planned behavior, and the authors found that determination predicts the entrepreneurial behavior of an individual.

Autio and his colleagues (2001) later noted that starting a new business is a planned behavior for students. Based on the planned behavior theory presented by Ajzen (1991), there are three variables that help to determine if a behavior is performed, that is, the individual attitudes about a behavior to be implemented, subjective norms, and perceived behavioral control. Therefore, apart from identifying the level of entrepreneurial intention, this study also identified attitudes towards entrepreneurship, social norms, entrepreneurial efficacy and entrepreneurial knowledge according to student perception. As of the present, there are no comparative studies of entrepreneurial intentions among the students in the two (Public) Education and Technical and Vocational Education Training (TVET) institutions in Malaysia that are being studied (NYSIs and community colleges). Therefore, the second objective of this study is to identify the differences in entrepreneurial intentions between the NYSI and community college students in Malaysia.

\section{Objective of the Study}

\subsection{General Objective}

The general aim of this study is to identify the entrepreneurial intention levels among students at two (Public) Education and Technical and Vocational Education Training (TVET) institutions in Malaysia.

\subsection{Specific Objectives}

The specific objectives of this study can be summarized as follows:

- To determine the entrepreneurial intention levels, attitudes towards entrepreneurship, social norms, entrepreneurial efficacy and entrepreneurial knowledge according to perceptions; and

- To identify differences in entrepreneurial intentions between NYSI and community college students.

\subsection{Research Questions}

According to the research objectives, this study was performed to find the answers to a few questions as follows:

- What is the entrepreneurial intention level of TVET students?

- What are the students' attitudes towards entrepreneurship?

- What are the students' social norm levels?

- What is the student entrepreneurial efficacy level?

- What is the student knowledge level of entrepreneurship?

- Is there a significant difference in terms of entrepreneurship intentions between NYSI students and community college students?

\section{Literature Review}

\subsection{Entrepreneurship Education in TVET}

Student preparation for entrepreneurship has become even more important recently because researchers anticipate a future business landscape will be dominated by small firms and self-employment (Shinnar, Pruett, \& Toney, 2009). Therefore, exposure to entrepreneurship is needed to motivate students to engage in entrepreneurship after graduation and to avoid dependence on salaried work. According to Norasmah and Salmah (2011), entrepreneurship education and exposure to entrepreneurship training could profoundly change a person's perception of entrepreneurship. Research findings by Souitaris, Zerbinati, and Al-Laham (2007) found that a familiarization to entrepreneurship program for one semester (January-May) among 250 science and 
engineering students at two universities in Europe (London and Grenoble) led to higher entrepreneurial intentions. The authors used a pretest-posttest quasi-experimental research design, and data were collected before and after an entrepreneurship program.

According to Ivan, Rahim, Ramlah, and Rosini (2008) and Fretwell (2003), Technical and Vocational Education and Training (TVET) is often seen in the context of the economy, and the intention is to produce quality human resources who are not only able to compete in the global engineering market but also in other professions. Entrepreneurship provides space and opportunities for individuals to work on what the ideas they want to explore and create opportunities that allow for lucrative returns. Furthermore, this field provides an opportunity for all individuals to improve the economy and society. Research findings by Kourilsky and Walstad (2007) reported that teenagers actually want to achieve economic autonomy by becoming a business owner, and the authors reported the results of their study on small business owners. They found that small business owners also have the same motivation as the teenaged respondents, which is to achieve high economic autonomy.

In conclusion, entrepreneurship is very important part of a country's development strategy, and vocational education provides a range of skills that enable individuals who go through the education process to venture into the world of business after completing their studies. Therefore, entrepreneurship education should be embedded in the TVET curriculum either directly or indirectly in many countries including Malaysia. The purpose of embedding the curriculum is to enable graduates to compete in the job market and thus create self-employment. Most countries believe TVET system is capable of producing skilled workers and capable of creating alternative employment by encouraging students to venture into entrepreneurship. If the students do not become entrepreneurs, at least they will receive the benefits of an entrepreneurship education that teaches them to be creative and innovative at problem solving and innovation and helps them adapt to changes.

\subsection{Development of Entrepreneurship Education (TVET) in Malaysia}

Through various government-appointed agencies, the Malaysian government has focused on Technical and Vocational Education and Training (TVET) by allocating large amounts of resources to infrastructure development and training centers. Although there are various institutions of technical and vocational education and training, Public Skills Training Institutes (PSTI) continues to play a major role in Malaysia (Kirchberger, 2008). The Malaysian Skills Certification System (VCLS) and the development of National Occupational Skills Standards (National Occupational Skills Standard-NOSS) for all skills training are coordinated by the Department of Skills Development (DSD) (Kirchberger, 2008) in accordance with the needs and developments of technology and the economy (Department of Skills, 2010).

Technical and Vocational Education and Training (TVET) institutions offer skills courses at the certificate level, advanced certificate, a diploma level, and advanced diploma. Among these institutions are the Department of Manpower Training Institute (ILJTM) under the Department of Human Resources [consisting of twenty-two (22) Industrial Training Institutes (ILP), four (4) Higher Technology Training Centres (ADTEC) and a Japan-Malaysia Technical Institute (JMTI), the National Youth Skills Institute (NYSI) under the Ministry of Youth and Sports, Majlis Amanah Rakyat (MARA) under the Ministry of Rural and Regional Development, the Centre for Instructor and Advanced Skill Training (CIAST) under the Department of skills development, community colleges under the Department of Community Colleges, Polytechnics under the Department of Polytechnic and the National Agricultural Training Council (NATC) under the Ministry of Agriculture and Agro-based Industry.

Two institutions of the Education and Technical and Vocational Education Training (TVET) in Malaysia were studied, namely community colleges and NYSI. The effectiveness and positive development of the community colleges in many countries has led Malaysia to adopt and adapt the methods of this educational system into the nation's educational system. According to Barbee (1972), community college is an instrument that has great potential to motivate youths with a lower tendency to pursue academics to study further after secondary school. Community colleges are able to enhance creativity and passion in adults as well as pave the way for a new generation to achieve a degree of success that is greater than that of their parents (Ashmore, 2001).

In Malaysia, the community college vision is to be a center of educational excellence in the fields of technology, business and service industries in addition to being capable of producing high-morality graduates in accordance with the National Education Philosophy. The mission is to expand educational access and improve the socio-economic status and well-being of society through training, skills and lifelong learning programs. According to Bettencourt (1980), vocational education can provide the best environment for entrepreneurship training to the students. This is because vocational education provides a range of skills that enable the individual who goes through this educational process to venture into the world of business after completing their studies. 
Therefore, regardless of the career choice of students in vocational training institutions, they still receive all the benefits of entrepreneurship education, which teaches creative problem-solving skills, innovation, and the ability to adapt to change, among others.

In his argument about entrepreneurship education in vocational education, Ashmore (1990) stated that entrepreneurship education provides many benefits to students. Among these benefits are a career plan, increased understanding and awareness of opportunities and responsibilities to the economy, providing a solid understanding of business fundamentals, applying skills acquired through vocational programs, studying entrepreneurship in the community to explore new business opportunities, increased self-understanding by looking at the positive and negative factors of that option before choosing entrepreneurship as a career, orientation to change, creativity and making business decisions (Ashmore, 1990).

On the same track, entrepreneurship education in Malaysia has been implemented as one of the strategies in the Outline Perspective Plan (OPP 3rd). The aim of the plan is to increase the number of skilled human resources, increase the ability to develop innovation and technology, and encourage businesses to achieve commercial and industrial community goals by the year 2020 (Malaysia, 2006). The provision of infrastructure and adequate financial resources, qualified academic staff, research and innovation and lifelong learning is at the core of this implementation (Ministry of Higher Education Malaysia, 2007). Not only is there an emphasis on the acquisition of knowledge and technical skills in its fields of study, but NYSIs also ensure that the students have excellent human capital qualities and that they are self-reliant in the employment sector through human development subjects, general subjects and core abilities.

Entrepreneurship is one of the components of human development subjects that is explored at the National Youth Skills Institute (NYSI). Regardless of their course and level of study, the trainees at the National Youth Skills Institute (NYSI) are being exposed to entrepreneurship through the same entrepreneurship module. They are exposed to the basic concepts of entrepreneurship, entrepreneurial motivation, business establishment, business records and documents, basic accounting, marketing and business communication. Aside from introducing business opportunities and financing facilities, the institute also aims to foster the entrepreneurial potential of students at NYSI. More importantly, the real purpose of entrepreneurial development among young people is to encourage them to choose self-employment as a career option.

\subsection{Theory-Related Model of Entrepreneurship Intention}

In an educational context, career selection is literally planned, which involves cognitive processes (Pittaway \& Cope, 2007). The same is true of entrepreneurial careers. Therefore, to identify the students who want to become entrepreneurs and to uncover the factors that influence individual decisions to set up new businesses, a researcher in the field of entrepreneurship highlighted various theoretical models in their study. The aim is to ensure that research can be performed in accordance with the academic track and does not deviate from the topic at hand. According to Zakaria (2010), a study that is not based on theory is a study without a sequence of events that does not depend on a logical framework. Such conditions will produce irregular and subjective interventions (Zakaria, 2010). That is the reason why of the use of these theoretical models is important. They become a frame of reference for study and act as guides in the research process. The use of a theoretical model also helps to explain factors for how individuals are likely to behave, feel and think. Hence, an intervention can be made on the basis of these assumptions. This result would strengthen the discussion of research as well as offer an opportunity to increase understanding and predict entrepreneurship ability.

With respect to entrepreneurship intentions, a scrutiny of previous studies by Liñán, Urbano, and Guerrero (2011) and Liñán and Santos (2007) identified two primary theoretical models of entrepreneurship that have been proposed, which are the entrepreneurial event by Shapero and Sokol (1982) and the theory of planned behavior by Ajzen (1991). According to Liñán and colleagues (2011), the model presented by Shapero and Sokol (1982) focuses on phenomena that occur during entrepreneurial activity, and the model by Ajzen (1991) describes how the cultural and social environments affect human behavior. Apart from Liñán and colleagues (2011), the study of entrepreneurship intention by Rozita, Ahmad, and Yuserrie (2010) in polytechnic students in Malaysia and a study by Suhaili and Azlan (2006) about the entrepreneurial tendencies of Muslim students at the University of Malaya is based on theory of planned behavior by Ajzen (1991).

Another study by Ramayah and Zainon (2005) on 1281 students at the University of Science, Malaysia (USM) was also performed by using the same theoretical model. This study shows that the theory of planned behavior is the basic theory that is often used to predict a person's behavior in the future, especially in the context of entrepreneurial careers. In addition, there are also other theoretical models for addressing researchers' entrepreneurial intention approaches. Among them are the Bird Model (1988), which was later adopted and 
developed by Boyd and Vozikis (1994) and Davidsson's (1995) entrepreneurship intention model. In fact, previous studies also show that not just one theoretical model can be used in a single study. However, various theoretical models can be made to practice conceptualizing the problem/question based on past, current and future behavior.

For example, a Malaysia study by Zaidatol and Hisyamuddin (2009) entitled "Choice of Self-Employment Intentions Among Secondary School Students" adopted a number of theoretical models as a reference frame such as the theory of planned behavior (Ajzen \& Fishbein, 1980) and the Krueger and Carsrud entrepreneurship intention model (1993) and the social learning theory of Bandura (1997, 1982). Similarly, a study by Ahmad Yasruddin, Nik Abdul Aziz and Nik Azyyati (2011) about entrepreneurial intention put forward two theory models as a basis for their study, that is, the theory of planned behavior by Ajzen (1991) and the entrepreneurial potential model by Krueger and Brazeal (1994). Apart from Ahmad Yasruddin and colleagues (2011), empirical studies performed by Veciana, Aponte, and Urbano (2005) to evaluate and compare attitudes towards entrepreneurship and business creation by university students in Catalonia and Puerto Rico also propose a model that focuses on intentions as a predictor for entrepreneurial behavior by Krueger and Brazeal (1994) in their study as an alternative to two other models, namely the model of entrepreneurial event by Shapero and Sokol (1982) and the theory of planned behavior by Ajzen (1991).

Based on a literature review, this study also put forward two models of primary theories on intention that are often used by researchers who are studying entrepreneurship intention approaches, namely Ajzen's theory of planned behavior and Shapero's model of entrepreneurial event. In addition, there are several theoretical models of entrepreneurial intentions that were adapted into these two major theoretical models, and they are also presented as suggested by researchers of the entrepreneurial intention approach by Bird (1988), Boyd and Vozikis (1994), and Davidson (1995).

\subsection{Entrepreneurship Knowledge}

The challenges and competition of the future require the younger generation of today to have a repertoire of knowledge, skills and personality and personal qualities that are appropriate and valuable for enhancing the country's competitiveness and strengthening the country's position (national competitiveness) compared with other developed countries. The K-economy is an economic policy that makes knowledge a key factor in leading the growth of a country. There is an emphasis on developing and using the combined knowledge along with information (knowledge and information) that is used strategically to generate and increase the level of socio-economic growth and development. According to Baughn, Cao, Le, Lim, and Neupert (2006), although there are previous studies on the influence of motivation as the driving force of a participation in entrepreneurship, studies on the technical and business knowledge required for entrepreneurship were inadequate.

Liñán et al. (2011) studied the factors that influence the level of entrepreneurial intention, and they reported that a high level of knowledge about entrepreneurship can contribute to a more realistic perception of entrepreneurial activity and will affect one's entrepreneurial intentions. This study is consistent with studies by Mohd Khata and Ahmad Firdaus (2012), who reported that a respondent's tendency to engage in entrepreneurship is affected by exposure to entrepreneurial courses during study. A respondents' propensity will be higher if their exposure to entrepreneurship courses was stressed during their studies at IKM (Mohd and Ahmad, 2012). The mean value obtained for the variable is the highest at 4:09 compared with the attitudes factor (mean $=3.95$ ), motivational factors (mean $=3.80$ ) and social support factors (mean = 3.70). However, the findings of Cheng, Chan, and Amir (2009), who studied the relations between knowledge of entrepreneurship and a desire to start a business upon graduation contrasts with the findings of Liñán and colleagues (2011) and Mohd and Ahmad (2012). Cheng et al. (2009) found that the relation was not significant $(r=0.072, p=0.214)$.

A very significant investment in education to develop human capital resources must be ensured to be worthwhile. According to the 9th Malaysia Plan (RMK-9), no attempt was ruled out in the government's commitment to develop entrepreneurs in this country (Malaysia, 2006). The government has developed and implemented various policies and programs and has provided the infrastructure to facilitate passage into the world of business entrepreneurship, nurture the spirit of entrepreneurship and educate potential entrepreneurs through education and training as well as the provision of financial and non-financial support. Assuming that they have received adequate exposure to the working environment as well as the quality of entrepreneurial knowledge and technical skills received, especially in the field of study, students who attend the Technical and Vocational Education and Training (TVET) system such as NYSI and community colleges should have high knowledge efficiency of a particular field of employment including entrepreneurship knowledge. 
Therefore, identifying respondents' entrepreneurial knowledge is an added value to the identification of the level of entrepreneurial attitudes, self-efficacy and social norms as stated in the theoretical model of intention presented in this study. The result is that this literature review highlights the need to identify the level of entrepreneurial knowledge among trainees in the Public Skills Training Institute (PSTI) in the context of a more comprehensive knowledge of entrepreneurship, and the knowledge required for a Small and Medium Enterprise (SME) is not limited solely to the content of the modules they learned in the classroom.

\section{Method}

This research used the survey to look closely at student entrepreneurial intentions during their pursuit of vocational training at two Technical and Vocational Education and Training (TVET) institutions in Malaysia or at least to note when they exhibit entrepreneurial behavior. In the context of this study, behaviors resulting from a number of variables were studied. The first factor is the attitude towards entrepreneurship, the second factor is the social norm, namely the social support available to students, which can influence their thinking about whether to do something (become entrepreneurs); and the third factor is student self-belief in their ability to engage in entrepreneurial behaviors. Apart from these three variables, this study also surveys students based on their perceptions of the entrepreneurial knowledge they possess as a result of the entrepreneurship education and industry training they received.

\subsection{Population and Sampling}

The population was made of students in their final semester of Electrical Technology Certificate courses (a full-time program) at two Technical and Vocational Education and Training institutions in Malaysia, namely community colleges and NYSI. According to Fayolle and Gailly $(2004,2005)$, the sampling was easy to use and often used in entrepreneurship research. A previous study found that graduates of tertiary institutions aged 25 to 34 showed a higher tendency towards starting their own ventures (Bosma, Jones, Autio, \& Levie, 2008).

This study used random cluster sampling because the study population is geographically scattered. This method is also suitable because of the difficulty of selecting individual population samples and the very high cost involved (Wiersma, 2005). However, researchers did not divide the community colleges and NYSIs according to geographical clusters of northern, central, southern, eastern Peninsular Malaysia and East Malaysia. Instead, the researchers divided the sample selection according to the community college and NYSI cluster, for the 19 community colleges and 4 NYSIs in Malaysia, which then have the opportunity to be selected as a sample. This approach was used because the number of students is significantly different if the study population is grouped geographically.

A total of 513 students consisting of 229 students from NYSI and 284 community college students were selected for this study. This group of student has also completed Industrial Training (IT). Next, based on a random sampling schedule by Bartlett, Kotrlik, and Higgins (2001), researchers make sample size calculations for this study. The result of the calculation showed that for a minimum size with a sample of 235 people, a total of 105 (44.6\%) students are required from NYSI and 130 (55.4\%) from community colleges. The researchers then use the fishball method for selecting a cluster from community colleges and NYSIs, which will be the sample for this study.

As a result, from the cluster of nineteen community colleges and four NYSIs listed, twelve clusters (ten from the community colleges and two from NYSIs) were selected for inclusion in this study. Next, the researchers distributed questionnaires to a total of 289 students from a selected cluster of twelve. This amount far exceeds the minimum recommended amount. In this way, we can address the problem that occurs if the amount of returned questionnaires is inadequate and likely incomplete. The total returned questionnaires that could be used was 262 , which is 90.7 percent of the total questionnaires that were distributed.

\subsection{Instrument}

A quantitative approach was used in this study, and a questionnaire is the primary instrument used to collect data from the respondents. The questionnaires were taken from previous research with demonstrated validity and high reliability, and they include several sets of questions in Parts A, B, C, D, E and F. Generally, a total of 14 question items submitted in Part A were related to the demographic characteristics of respondents such as the respondents' background, education and experience leading to entrepreneurship and the choice that will be made after completing their training in the future.

Parts $\mathrm{B}$ to $\mathrm{F}$ of the questionnaire were submitted to test the objectives and research questions. These parts included the aspects to be studied, the entrepreneurship intention (Part B), attitudes towards entrepreneurship (Part C), social norms (Part D), entrepreneurship efficacy (Part E) and the efficiency of entrepreneurial 
knowledge (Part F) according to student perceptions. The entire set of questionnaires in Parts B to F consisted of 90 questions and was measured by using a 5-point Likert Scale.

\subsection{Data Analysis}

The researchers began the process of data analysis by producing descriptive statistics. The five questions in this study only focus on the level and pattern of entrepreneurship intentions, attitudes towards entrepreneurship, entrepreneurial efficacy, social norms, and entrepreneurial knowledge according to student perception. This process involves only one variable from a set of analyzed data. The data are then summarized using means, frequencies and percentages. According to Steinberg (2008), the mean accounts for all the scores in data sets, and the most accurate values represent a set of data. The mean score level of each variable (entrepreneurial intention, attitude, entrepreneurial efficacy, social norms and student perceptions of the entrepreneurial knowledge they possessed) was then measured according to the interpretation chart of mean scores (Table 1) obtained by Norasmah and Sabariah (2007) and Norasmah and Salmah (2011). Research question number six was aimed at identifying differences in entrepreneurial intentions between the NYSI students and community college students. Independent sample $t$-tests were used for comparing the means of two independent samples.

Table 1. Interpretation of mean scores

\begin{tabular}{ll}
\hline Mean Score & Interpretation of Mean Score \\
\hline $1.00-2.00$ & Low \\
$2.01-3.00$ & Moderately Low \\
$3.01-4.00$ & Moderately High \\
$4.01-5.00$ & High \\
\hline
\end{tabular}

(Sources: Norasmah \& Sabariah, 2007; Norasmah \& Salmah, 2011)

\section{Results and Discussion}

\subsection{Description of Respondents' Backgrounds}

The Electrical Technology Certificate program (full-time) was found to be dominated by male students, at $94.3 \%$, and it was only $5.7 \%$ female students. This is a normal phenomenon for engineering courses at any institution. Most of the engineering stream is dominated by male students. In terms of age breakdown, $52.3 \%$ of respondents were 20 years old, $19.5 \%$ of respondents were 21 years old, $14.5 \%$ of respondents 22 years old and $6.5 \%$ of the respondents were 23 years old. Respondents aged 24 years and above are a minority group $(7.3 \%)$ in the Electrical Technology Certificate program (full-time) in the Public Skills Training Institute (PSTI) in Malaysia.

The feedback also indicated that $29.8 \%$ of students reported that they had pursued education related to entrepreneurship at the upper secondary level and the remaining $70.2 \%$ did not. These findings give the impression that upper secondary education has provided exposure to the entrepreneurial experience. However, the percentage is quite small. This finding may be related to the fact that the subject offerings at the upper secondary level are quite limited for certain classes. In addition, $13.7 \%$ of respondents said that they had attended courses related to entrepreneurship, and $86.3 \%$ had never attended any course.

\subsection{What Is the Students' Entrepreneurial Intention Level?}

Overall, the mean score for the students' entrepreneurial intentions is high at 4.23 with a standard deviation of $0.73(\mathrm{n}=262)$. The details (Table 2) show that most of the students, or $154(58.8 \%)$ students, exhibited a high level of entrepreneurial intention. Apart from that, $86(32.8 \%)$ students showed a moderately high level of entrepreneurial intention and another 19 (7.3\%) students were medium low. Only three students $(1.1 \%)$ had a low level of entrepreneurial intention.

\subsection{What Is the Student Attitude Level towards Entrepreneurship?}

This section reported on attitude levels towards entrepreneurship according to the perception of surveyed students. Table 4.1 shows that students' attitudes towards entrepreneurship are generally high with a mean score $=4.03$ (S.D. $=0.47)$. When these findings are detailed, they show that a total of $125(47.7 \%)$ students have a high attitude towards entrepreneurship, 137 (52.3\%) students have a medium attitude level towards entrepreneurship, 128 (48.9\%) students had moderately high attitudes and only 9 (3.4\%) students had a 
moderately low level. Some of the students in the group have a poor attitude towards entrepreneurship (Table 2).

\subsection{What Are the Student Social Norm Levels?}

Social norms in the context of this study refer to the beliefs (perceptions) of students towards social pressure to perform or not perform entrepreneurial behavior. The various aspects considered here include the approval and support of family, friends and the people who are important to them (teachers/mentors) towards entrepreneurial activity and the perceptions of these three groups regarding the choice to become an entrepreneur. Apart from that, the cultural factors, values and norms within the country (Malaysia) around supporting entrepreneurial activity are also taken into account as important factors that influence student opinions on the idea or decision to become an entrepreneur. Out of the 262 students surveyed, the findings show that $1(0.4 \%)$ student has low social norms and $26(9.9 \%)$ students are at a moderately low level. Other than that, $138(52.7 \%)$ students showed a moderately high level of social norms and 97 (37.0\%) students had a high level of social norms. Overall, the mean score for the respondents' level of social norms is moderately high at 3.82 and the standard deviation is 0.59 (Table 2).

\subsection{What Is the Level of Entrepreneurial Efficacy?}

Student entrepreneurial efficacy refers to student beliefs and evaluations of their abilities to perform a variety of tasks as an entrepreneur and to serve as an entrepreneur. An analysis conducted for this study showed that 15 (5.7\%) students have moderately low entrepreneurial efficacy, $126(48.1 \%)$ students are at a moderate level and 119 (45.4\%) students have a high level of entrepreneurial efficacy. Only $2(0.8 \%)$ students have a low level of entrepreneurial efficacy. Overall, this study showed that the respondents have a moderately high level of entrepreneurial efficacy with a mean score of 3.99 (S.D. $=0.59$ ) as shown in Table 2.

\subsection{What Is the Level of Entrepreneurial Knowledge?}

Out of the 262 students surveyed, the findings show that $1(0.4 \%)$ student has low entrepreneurial knowledge, 19 (7.3\%) students have moderately low entrepreneurial knowledge, 141 (53.8\%) students have moderately high levels and the balance of 101 (38.5\%) students have a high level of entrepreneurial knowledge. Overall, the results of this study show that the mean scores for the respondents' level of entrepreneurial knowledge are moderately high, with a mean score of 3.93 and a standard deviation of 0.55 (Table 2). 
Table 2. Levels of entrepreneur intentions, attitudes towards entrepreneurship, social norms, entrepreneurship efficacy, and knowledge of entrepreneurship

\begin{tabular}{|c|c|c|c|c|c|c|}
\hline Variables & Mean Score & Level & $\mathrm{F}$ & $\%$ & Mean & S. D. \\
\hline \multirow{4}{*}{ Entrepreneur Intention } & $1.00-2.00$ & Low & 3 & 1.1 & \multirow{4}{*}{4.23} & \multirow{4}{*}{0.73} \\
\hline & $2.01-3.00$ & Moderately Low & 19 & 7.3 & & \\
\hline & $3.01-4.00$ & Moderately High & 86 & 32.8 & & \\
\hline & $4.01-5.00$ & High & 154 & 58.8 & & \\
\hline \multirow{4}{*}{ Attitude towards Entrepreneurship } & $1.00-2.00$ & Low & - & 0.0 & \multirow{4}{*}{4.03} & \multirow{4}{*}{0.47} \\
\hline & $2.01-3.00$ & Moderately Low & 9 & 3.4 & & \\
\hline & $3.01-4.00$ & Moderately High & 128 & 48.9 & & \\
\hline & $4.01-5.00$ & High & 125 & 47.7 & & \\
\hline \multirow{4}{*}{ Social Norms } & $1.00-2.00$ & Low & 1 & 0.4 & \multirow{4}{*}{3.82} & \multirow{4}{*}{0.59} \\
\hline & $2.01-3.00$ & Moderately Low & 26 & 9.9 & & \\
\hline & $3.01-4.00$ & Moderately High & 138 & 52.7 & & \\
\hline & $4.01-5.00$ & High & 97 & 37.0 & & \\
\hline \multirow{4}{*}{ Entrepreneurial Efficacy } & $1.00-2.00$ & Low & 2 & 0.8 & \multirow{4}{*}{3.99} & \multirow{4}{*}{0.59} \\
\hline & $2.01-3.00$ & Moderately Low & 15 & 5.7 & & \\
\hline & $3.01-4.00$ & Moderately High & 126 & 48.1 & & \\
\hline & $4.01-5.00$ & High & 119 & 45.4 & & \\
\hline \multirow{4}{*}{ Entrepreneurial Knowledge } & $1.00-2.00$ & Low & 1 & 0.4 & \multirow{4}{*}{3.93} & \multirow{4}{*}{0.55} \\
\hline & $2.01-3.00$ & Moderately Low & 19 & 7.3 & & \\
\hline & $3.01-4.00$ & Moderately High & 141 & 53.8 & & \\
\hline & $4.01-5.00$ & High & 101 & 38.5 & & \\
\hline
\end{tabular}

Notes. Minimum Mean $=1$; Maximum Mean $=5$.

\subsection{Is There a Significant Difference in Entrepreneurial Intentions Between NYSI and Community College Students?}

The results of the $\mathrm{t}$-test analysis $\left(\mathrm{t}{ }_{(260)}=.23, \mathrm{p}=.82\right)$ in Table 3 showed that the mean differences in student entrepreneurial intentions between NYSI students and community college students are not significant. This finding leads to the null hypothesis (Ho1), indicating that there is no significant difference in the entrepreneurial intention of NYSI students ( $m e a n=25.29$; S.D. $=4.22)$ with community college students (mean $=25.41$; S.D. $=$ 4.48). These findings explained that both groups of students (NYSI and community colleges students), do not differ in their entrepreneurial intentions (Table 3).

Table 3. Entrepreneurial intentions of NYI and community college students

\begin{tabular}{lllllll}
\hline Institutions & $\mathrm{M}$ & S.D. & M Differences & $D f$ & $t$-value & $P$ \\
\cline { 1 - 4 } NYSI & 25.29 & 4.22 & \multirow{2}{*}{0.12} & 260 & .23 & 0.82 \\
\cline { 1 - 4 } Community College & 25.41 & 4.48 & & & & \\
\hline
\end{tabular}

\section{Discussion and Conclusions}

The results showed that the student levels of entrepreneurial intentions in the surveyed Public Skills Training Institute (PSTI) was high (mean $=4.23$; S.D. $=0.73$ ). These findings support previous findings such as those of Mohd and Ahmad (2012), Reitan (1997), and Izquierdo and Buelens (2011). Through their research, Mohd and Ahmad (2012), Reitan (1997), and Izquierdo and Buelens (2011) show that exposure to entrepreneurship education can increase students' interest in entrepreneurial careers. The results showed that there are three items 
that have high mean scores out of the six items tested in this section, that is, "I'm ready to make anything to be an entrepreneur" (mean score $=4.33$ ), followed by the item "I've got the firm intention to start a company someday" (mean score $=4.28$ ) and the last one is, "I'm determined to create a firm in the future" (mean score = 4.25).

The study also found that the respondents have moderately high and high perceptions for three factors related to entrepreneurial intention (Table 1). They have high mean scores for attitudes towards entrepreneurship and moderately high mean scores for social norms and entrepreneurial self-efficacy. Attitudes towards entrepreneurship were measured on the basis of the subscale of specific attitude towards entrepreneurship that is associated with the identification and evaluation of business opportunities, networking, and communication abilities. Overall, the mean scores obtained for attitudes towards entrepreneurship factors were high according to the perception of the students involved in this study (mean $=4.03$; S.D. $=0.47$ ). The findings for respondent responses identified a few items such as "I believe it is crucial for success to be able to assess pros and cons of a business idea" (mean score $=4.21$ ) and "I feel good when I am able to visualize business opportunities" (mean score $=4.18)$.

These findings are basically consistent with studies by Norasmah and Salmah (2009), who found that the attitude level towards entrepreneurship among Graduate Entrepreneur Scheme program participants (Entrepreneurial Graduate Scheme) from 2003 to 2006 as a whole was high $($ mean = 4.30; S.D. = 0.358). In that study, Norasmah and Salmah (2009) found that respondents have a high attitude level towards entrepreneurship based on the details of the mean score between 4.21 to 4.42 for each attitude component towards specific entrepreneurship factors, namely the need for achievement $($ mean $=4.21$; S.D. $=0501)$, an internal locus of control (mean $=4.42$; S.D. $=0.386)$, competitiveness $($ mean $=4.24$; the S.D. $=0.433)$, monetary value $($ mean $=4.41$; S.D. $=0.436)$ and autonomy (mean $=4.16$; S.D. $=0.443$ ).

The study also supports the findings of Basu and Virick (2008) on the entrepreneurship intention among students at San Jose State University based on a model developed by Fishbein and Ajzen (1975). In their study, Basu and Virick (2008) reported that students who go through the process of entrepreneurship education have a more positive attitude towards entrepreneurial careers. The study involved 122 respondents, with $96.7 \%$ participating in full-time programs, and their average age is 23.4 years. These findings strengthen the discussion of attitudes towards entrepreneurship by using a review of previous studies by Izquierdo and Buelens (2011) and Norfadhilah and Halimah (2010). Both studies reported that student attitudes about becoming entrepreneurs are strongly related to a self-intention to work as an entrepreneur. According to Norfadhilah and Halimah (2010), the study found that attitude is an important factor in influencing student entrepreneurial intentions. Most respondents in the study hope that a positive attitude towards entrepreneurship can be maintained until they have started their business in the future (Norfadhilah \& Halimah, 2010).

Apart from the attitude factor, these findings also support some earlier findings about the influence of socialization in the development of entrepreneurial intentions. Overall, the study reported moderately high social norm variables $($ mean $=3.82$; S.D. $=0.59)$. A detailed analysis was then performed on the three sub-scales in the social norms variable, namely the approach value, subjective norms and cultural environment. As a result, the study found that students who receive a positive perception from the person who is considered important in their lives (family, close friends and teacher/mentor) assist in developing their intention to become an entrepreneur compared with environmental factors. This matter may be referred to subscale mean scores of family support, friends and individuals who are considered important in the lives of students (e.g., teacher/mentor) and has a 4:09 mean score (S.D. $=0.65)$ for the approach value and a 4:21 mean score (S.D. $=0.63)$ for subjective norms.

By contrast, cultural factors have less value to most respondents in influencing them to perform entrepreneurial activities. A mean score $=3.42$ (S.D. $=0.99$ ) was obtained for the cultural factors students. This finding is consistent with previous studies by Baughn and colleagues (2006). Entrepreneurship studies by Baughn and colleagues (2006) on 782 students majoring in business entitled "Normative, Social and Cognitive Predictors of Entrepreneurial Interest in China, Vietnam and the Philippines" reported that aspects of the cultural, economic and political situation in the study countries influenced their students' entrepreneurial intentions. However, a detailed analysis of the study by Baughn and colleagues (2006) later showed that family support factors have a greater impact in reducing entrepreneurial activity. Baughn and colleagues (2006) later reported that the demands/needs of the family can reduce a person's interest and commitment towards the field of entrepreneurship.

Study results that show a moderately high level of entrepreneurial efficacy (mean $=3.99$; S.D. $=0.59)$ support the findings of previous studies by Zaidatol and Bagheri (2011), who reported that the mean score of 
entrepreneurial efficacy in Malay technical students was generally moderate. This finding reflects the fact that the surveyed Technical and Vocational Education and Training (TVET) students have self-confidence and the ability to become an entrepreneur because of their moderately high perception of entrepreneurial efficacy. High efficacy will produce high entrepreneurial intentions. According to Baughn and colleagues (2006), entrepreneurial interest is positively related to the individual's perception that he/she possesses the skills (self-efficacy) needed to initiate and sustain a new business. Baughn and colleagues (2006) confirmed that there are relations between entrepreneurial self-efficacy and entrepreneurial intention $(r=.47, \mathrm{p}<0.01)$ among the respondents $(\mathrm{n}=782)$ in each of the countries surveyed. They also found that there are differences in entrepreneurial self-efficacy and entrepreneurial intention among male respondents and female respondents. Male respondents had a higher score for self-efficacy $(r=0: 16, \mathrm{p}<0.01)$ than female respondents. An analysis performed by Kiu (2006) found that self-efficacy is significantly different according to the gender ( $\mathrm{t}[374]=$ $2.851, \mathrm{p}<.05)$, increasing age $(\mathrm{F}[4,371]=2437, \mathrm{p}<.05)$ and work experience $(\mathrm{F}[4,371]=5872, \mathrm{p}<.05)$ of an individual.

Overall, this study also showed that the respondents' entrepreneurial knowledge is moderately high with a mean score of 3.93 and a standard deviation of 0.55 . The study identified the level of respondent entrepreneurial knowledge based on 4 specific entrepreneurial factors, including the identification and evaluation of business opportunities, networking and communication. An example of these items is "one of my strengths is the ability to perceive unresolved problems that lead me to formulate a business idea." These findings show that the networking subscale has the highest mean score (mean score $=4.05$; S.D. $=0.66$ ), followed by the evaluation of business opportunities (mean score $=3.96$; S.D. $=0.59)$; the next is communication (mean score $=3.93$; S.D. $=0.59$ ), and the lowest is the identification of business opportunities (mean score $=3.92$; S.D. $=0.60$ ). The study concluded that out of 262 students surveyed, (0.4\%) of students have low entrepreneurial knowledge, 19 (7.3\%) of students have moderately low entrepreneurial knowledge, 141 (53.8\%) students have moderately high knowledge, and the remaining $101(38.5 \%)$ students have high entrepreneurial knowledge. Furthermore, the $t$-test is used to indicate whether there is a difference in the means for entrepreneurial intention between NYSI students and community college students. There was no reported significant difference in the entrepreneurial intentions of NYSI students $($ mean $=25.29 ;$ S.D. $=4.22)$ and community college students $($ based on the mean $=25.41$; S.D. $=4.48)$.

In summary, this study further expanded empirical knowledge in the field of entrepreneurship education, which is specialized for the relation between education and entrepreneurial intention as well as several other factors that are also mentioned as important in the previous studies. The moderately high and high perceptions indicated by NYSI and community college students for every factor studied here showed that entrepreneurship education is important in the development of entrepreneurial intentions among students. Entrepreneurship education can increase student awareness about careers that exist in the field of entrepreneurship. Therefore, to ensure intentions of choosing the entrepreneurship profession among students, especially students at Technical and Vocational Education and Training (TVET) in Malaysia, an entrepreneurship education curriculum should always be improved so that it is able to nurture a culture of entrepreneurship and thus increase student intention to choose entrepreneurship as a career path. Furthermore, the government is currently encouraging young people to engage in entrepreneurship through the provision of facilities to provide motivation to the community in general and to young people in particular.

\section{References}

Ahmad-Yasruddin, M. Y., Nik-Abdul-Aziz, N. M., \& Nik-Azyyati, N. J. (2011). Students' entrepreneurial inclination at a Malaysia polytechnic: A preliminary investigation. International Education Studies, 4(2), 198-207.

Ajzen, I. (1988). Attitudes, personality and behavior. Chicago, Illinois: The Dorsey Press.

Ashmore, M. C. (1990). Entrepreneurship in vocational education. In C. A. Kent (Eds.), Entrepreneurship education: current developments, future directions (pp. 11-229). New York: Quorum Books.

Autio, E., Keeley, R. H., Klofsten, M., Parker, G. G., \& Hay, M. (2001). Entrepreneurial intent among students in Scandinavia and in the USA. Enterprise and Innovation Management Studies, 2(2), 145-160. http://dx.doi.org/10.1080/14632440110094632

Bahagian Pembangunan Kemahiran IKBN. (2010). Panduan dan peraturan pelaksanaan sistem penilaian latihan kemahiran di Institut Kemahiran Belia Negara (IKBN). Putrajaya: Bahagian Pembangunan Kemahiran, Kementerian Belia dan Sukan.

Barbee, D. (1972). A systematic approach to Community College education. Colorado: Auerbach Publishers Inc. 
Bartlett, J. E., Kotrlik, J. W., \& Higgins, C. C. (2001). Organizational research: determining appropriate sample size in survey research. Information Technology, Learning, and Performance Journal, 19(1), 43-50.

Basu, A., \& Virick, M. (2008). Assessing entrepreneurial intentions amongst students: A comparative study. Proceedings of the NCIIA 12th Annual Meeting (pp. 79-86). Washington DC: National Collegiate Inventors and Innovators Alliance (NCIIA), Hadley, MA, USA.

Baughn, C. C., Cao, J. S., Le, L. T., Lim, V. A., \& Neupert, K. E. (2006). Normative, social and cognitive predictors of entrepreneurial interest in China, Vietnam and the Philippines. Journal of Developmental Entrepreneurship, 11(1), 57-77. http://dx.doi.org/10.1142/S108494670600026X

Bird, B., \& Jelinek, M. (1988). The operation of entrepreneurial intentions. Entrepreneurship Theory and Practice, 13(2), 21-29.

Bosma, N., Jones, K., Autio, E., \& Levie, J. (2008). Global entrepreneurship monitor-2007 Executive Report. Babson College, London Business School and Global Entrepreneurship Research Consortium (GERA).

Boyd, N. G., \& Vozikis, G. S. (1994). The influence of self-efficacy on the development of entrepreneurial intentions and actions. Entrepreneurship Theory and Practice, 63-74.

Cheng, M. Y., Chan, W. S., \& Amir, M. (2009). The effectiveness of entrepreneurship education in Malaysia. Education and Training, 51(7). http://dx.doi.org/10.1108/0040091091099275

Chou, C.-M., Shen, C.-H., Hsiao, H.-C., \& Chen, S.-C. (2010). A study on constructing entrepreneurial competence indicators for business department students of vocational and technical colleges in Taiwan. World Transactions on Engineering and Technology Education, 8(3), 316-320.

Davidsson, P. (November 23-24, 1995). Determinants of entrepreneurial intentions. Paper prepared for the RENT IX Workshop. Piacenza, Italy.

European Commission. (2009). Entrepreneurship in Vocational Education and Training. Final Report conducted by the European Commission and Experts, 1-45.

Fayolle, A., \& Gailly, B. (2005). Using the Theory of Planned Behaviour to assess entrepreneurship teaching programmes. Center for Research in Change, Innovation and Strategy of Louvain School of Management.

Fayolle, A., \& Gailly, B. (4-7 July 2004). Using the Theory of Planned Behaviour to assess entrepreneurship eaching programs: A first experimentation. 14th Annual IntEnt Conference University of Napoli Federico II. Italy.

Federal Ministry of Education and Research (BMBF). (2005). Reform of Vocational Education and Training in Germany: The 2005 Vocational Training Act. Bonn, Berlin: Federal Ministry of Education and Research (BMBF).

Fretwell, D. (2003). A framework for evaluating vocational education and training. European Journal of Education, 38(2), 177-190. http://dx.doi.org/10.1111/1467-3435.00137

Haftendorn, K., \& Salzano, C. (2004). Facilitating youth entrepreneurship (Part II): A directory of awareness and promotion programmes in formal and non-formal education. Geneva: International Labour Office.

Hamidi, D. Y., Wennberg, K., \& Berglund, H. (2008). Creativity in entrepreneurship education. Journal of Small Business and Enterprise Development, 15(2).

Hisyamuddin, H. (2010). Pendidikan keusahawanan dan tekad keusahawanan. In Z. A. Hassan (Eds.), Memperkasa Tekad Keusahawanan Pelajar (pp. 1-8). Serdang: Penerbit Universiti Putra Malaysia.

Ivan, H., Rahim, B. A., Ramlah, H., \& Rosini, A. (2008). Model sistem pendidikan dan latihan teknikal-vokasional. In M. I. Abdullah-Mat-Rashid (Eds.), Pendidikan Teknikal dan Vokasional (pp. 3-22). Serdang: Penerbit Universiti Putra Malaysia.

Kementerian, P. T. M. (2007). Pelan Strategik Pengajian Tinggi Negara Melangkaui Tahun 2020. Putrajaya: Kementerian Pengajian Tinggi Malaysia.

Kirchberger, A. (2008). TVET Developments in Europe, Africa and Asia. Paris: World Bank Institute.

Kiu, T. L. (2006). Pengaruh faktor terpilih terhadap efikasi kendiri guru sekolah menengah di negeri Sarawak. Serdang: Tesis yang dikemukakan kepada Sekolah Pengajian Siswazah, Universiti Putra Malaysia, sebagai memenuhi keperluan untuk Ijazah Doktor Falsafah.

Kourilsky, M. L., \& Walstad, W. B. (2007). The entrepreneur in youth: An untapped resource for economic 
growth, social entrepreneurship, and education (New Horizons in Entrepreneurship). Northampton: Edward Elgar Publishing.

Liñán, F., \& Santos, F. J. (2007). Does social capital affect entrepreneurial intentions? International Advances in Economic Research, 13, 443-453. http://dx.doi.org/10.1007/s11294-007-9109-8

Liñán, F., Urbano, D., \& Guerrero, M. (2011). Regional variations in entrepreneurial cognitions: Start-up intentions of university students in Spain. Entrepreneurship \& Regional Development, 23, 187-215. http://dx.doi.org/10.1080/08985620903233929

Malaysia. (2006). Rancangan Malaysia Kesembilan 2006-2010. Putrajaya: Unit Perancang Ekonomi, Jabatan Perdana Menteri.

Matlay, H. (2008). The impact of entrepreneurship education on entrepreneurship education on entrepreneurial outcomes. International Journal Entrepreneurship and Small Business, 15(2).

Mohd, K. J., \& Ahmad, F. A. H. (2012). Kecenderungan pelajar tahun akhir di institut kemahiran Mara terhadap bidang keusahawanan. Journal of Educational Management, 5, 16-33.

Norasmah, H. O., \& Sabariah, I. (2007). Tahap tingkah laku kognitif keusahawanan di kalangan pelajar dan remaja. In N. H. Othman, \& H. Harun (Eds.), Keusahawanan Remaja Malaysia (pp. 78-102). Serdang: Penerbit Universiti Putra Malaysia.

Norasmah, H. O., \& Salmah, I. (2011). Kecenderungan terhadap pemilihan kerjaya keusahawanan mengikut persepsi peserta skim usahawan siswa. Jurnal Teknologi, 56, 47-63.

Norfadhilah, N., \& Halimah, H. (2010). Entrepreneurial career aspirations among IPTA students. Jurnal Pendidikan Malaysia, 11-17.

Pittaway, L., \& Cope, J. (2007). Entrepreneurship education: A systematic review of the evidence. International Small Business, 25(5), 479-510. http://dx.doi.org/10.1177/0266242607080656

Ramayah, T., \& Zainun, H. (2005). Entrepreneurial intention among the students of Universiti Sains Malaysia. International Journal of Management and Entrepreneurship, 1(1), 8-20.

Reitan, B. (1997). Where do we learn that entrepreneurship is feasible, desirable and/or profitable? A look at the processes leading to entrepreneurial potential. Paper presented to the ICSB World Conference (pp. 1-18).

Rozita, M., Ahmad, O., \& Yuserrie, Z. (2010). Psychological characteristics and entrepreneurial intention among Polytechnic Students in Malaysia: A Theory of Planned Behavior Approach. ISE-SODA (pp. 55-69). Universiti Utara Malaysia and Ministry of Higher Education.

Schoof, U. (2006). Stimulating Youth Entrepreneurship: Barriers and Incentives to Enterprise Start-ups by Young People. Geneva: International Labour Office.

Shartrand, A., Weilerstein, P., Besterfield-Sacre, M., \& Olds, B. M. (2008). Assessing student learning in technology entrepreneurship. 38th ASEE/IEEE Frontiers in Education Conference (pp. 12-17). Saratoga Springs, NY: IEEE.

Shen, P., \& Chai, L. (2006). Changing entrepreneurial perception and developing entrepreneurial competencies through experiential learning: Evidence from entrepreneurship education in Singapore's Tertiary Education Institution. Journal of Asia Entrepreneurship and Sustainability, 11(2).

Shinnar, R., Pruett, M., \& Toney, B. (2009). Entrepreneurship education: Attitudes across campus. Journal of Education for Business, 151-158. http://dx.doi.org/10.3200/JOEB.84.3.151-159

Souitaris, V., Zerbinati, S., \& Al-Laham, A. (2007). Do entrepreneurship programmes raise entrepreneurial intention of science and engineering students? The effect of learning, inspiration and resources. Journal of Business Venturing, 566-591. http://dx.doi.org/10.1016/j.jbusvent.2006.05.002

Steinberg, W. J. (2008). Statistics Alive! Sage Publications, Inc.

Suhaili, S., \& Azlan, A. (2006). Keusahawanan di kalangan mahasiswa: Kajian kecenderungan pelajar Muslim di Universiti Malaya. Jurnal Syariah, 14(1), 93-109.

Veciana, J. M., Aponte, M., \& Urbano, D. (2005). University students' attitudes towards entrepreneurship: A two countries comparison. International Entrepreneurship and Management Journal, 1, 165-182. http://dx.doi.org/10.1007/s11365-005-1127-5

Wang, Y., \& Verzat, C. (2011). Generalist or specific studies for engineering entrepreneurs? Comparison of 
French engineering students' trajectories in two different curricula. Journal of Small Business and Enterprise Development, 18(2). http://dx.doi.org/10.1108/14626001111127124

Wiersma, W. (2005). Research Methods in Education: An Introduction (Edisi ke-6). Massachusetts: Allyn and Bacon.

Zaidatol, A. P., \& Bagheri, A. (2011a). Malay secondary school students' entrepreneurial attitude orientation and entrepreneurial self-efficacy: A descriptive study. Journal of Applied Sciences, 11(2), 316-322. http://dx.doi.org/10.3923/jas.2011.316.322

Zaidatol, A. P., \& Bagheri, A. (2011b). Malay students' entrepreneurial attitude and entrepreneurial efficacy in vocational and technical secondary schools of Malaysia. Pertanika J. Soc. Sci. \& Humanities, 19(2), 433-447.

Zaidatol, A. P., \& Hisyamuddin, H. (2009). Choice of self-employment intentions among secondary school students. The Journal of International Social Research, $2 / 9$.

Zakaria, M. (2010). Pola pengetahuan, kefahaman dan penggunaan teori di kalangan kaunselor di Malaysia. Jurnal Kemanusiaan, 15.

\section{Copyrights}

Copyright for this article is retained by the author(s), with first publication rights granted to the journal.

This is an open-access article distributed under the terms and conditions of the Creative Commons Attribution license (http://creativecommons.org/licenses/by/3.0/). 